\title{
The Universal Plate Revisited
}

\author{
Emilia Calvo \& Roser Puig
}

Key Words: Astronomy, Instruments, al-Andalus, Transmission, Textual Criticism, Alfonsine Astronomy.

\begin{abstract}
The universal plate devised by ${ }^{c} \mathrm{Al} \overline{\mathrm{I}} \mathrm{Ibn}$ Khalaf al-Ṣaydalanī is a universal instrument of the 11th century al-Andalus. Among the Alfonsine Libros del Saber de Astronomia, there is a book which includes the treatise on its construction, the author of which is Isḥāq b. Sīd (Rabiçag) a collaborator of the King, and the treatise on the use which seems to be a translation from a lost original Arabic written by Ibn Khalaf. Although both treatises have been partially studied previously, there were many questions still unsolved. This paper presents new data regarding the morphology of the instrument, confirms the consistency between the description of the shape of the rete as described in both treatises, which had been questioned, and gives two chapters analysing the use of the mater in conjunction with the rete.
\end{abstract}

\section{Introduction ${ }^{1}$}

Over the past twenty-five years, a number of scholars have been involved in the study of Andalusian astronomical instruments serving all terrestrial latitudes. The earliest examples are the two plates by al-Zarqāli $\bar{i}^{2}$ the

\footnotetext{
${ }^{1}$ This paper was written with the support of the research project "Ciencia y Sociedad en el Mediterraneo Occidental en la Baja Edad Media" sponsored by the Spanish Ministerio de Educación y Ciencia (HUM2004-02511) and FEDER.

${ }^{2}$ Abū Ishāa Ibrāhīm b. Yahyyā al-Naqqāsh known as Ibn al-Zarqālluh or walad al-Zarqiyāl or al-Zarqālī. See Șāi id, p. 180; Suter, 1900, n² 255, pp. 109-111; Brockelmann, 1937, p.
} 
zarqāliyya plate (Puig 1987 and 1987a) and the shakkäziyya (Puig 1985 and 1986 and Calvo 1989), and the universal instrument of 'Alī b. Khalaf al-Saydalanī, equipped with a rete. In the only version that has survived, the treatise on this latter instrument refers to it as lámina universal or orizon universal, which means universal plate.

In spite of the research carried out so far, several questions concerning the universal plate remain not only unsolved, but untouched. The treatise on its use ${ }^{3}$ has not been thoroughly analysed, nor have the construction and characteristics of the rete - a very important part of the instrument been properly studied.

The fact that no in-depth study has been carried out is probably due to the many obstacles that the researcher has to contend with. First, the original Arabic text of the treatise on the use is not extant. We have only a translation, commissioned by King Alfonso X the Wise (1252-1284) written in old Castilian. The antique nature of the language used in this text and the great abundance of technical and phraseological Arabic expressions make its understanding especially difficult. Second, we do not have an original treatise of the plate's construction, either in Arabic or in translation. We have only the treatise written by Rabiçag (Ishāa b. Sĩd), one of the king's astronomers, which precedes the treatise on the use, and is also written in old Castilian ${ }^{4}$. Third, no instruments have survived. Although al-Zarqālī's plates are based on the same projection, their specific characteristics (for instance, they do not have a rete) place them apart from 'Alī b. Khalaf's instrument. Fourth, some recently found instruments do have a rete, and so resemble the universal plate, but the rete is different from the one described in the treatise under study.

862; Sarton, 1927, vol. I, pp. 758-759; Millás Vallicrosa, 1943-1950; Vernet, DSB, pp. 592- 595; Samsó, EI, pp. 461-462; Calvo, 1997, pp. 415-416; Puig, 2003, p. 75.

${ }^{3}$ In a recent article, A. Moreno asserted that "the illustration of the rete in the Libros del Saber associated with Rabiçag's treatise on the construction of the instrument is a distortion of the rete which 'Alī ibn Khalaf had in mind", see Moreno et al. 2002, p. 336. The author therefore proposes a new form for the rete, but does not seem to consider the treatise on its use compiled by 'Alī ibn Khalaf. As we will show later on in this paper (Appendix 1), the instructions of use would be impossible to follow with a modified rete like the one proposed by Moreno unless we also modify 'Alī ibn Khalaf's text.

${ }^{4}$ The first chapter of this treatise, describing the construction of the mater, has been studied by Samsó (1987) in a comparison with the construction of al-Zarqāli’s plate. He concludes that the drawing of the lines of the projection of the face coincide in the two, except in the description of the drawing of the meridians of the universal plate where there is a copying error. This error is easy to avoid for anyone familiar with the projection. 
The images available to researchers, then, are the drawings accompanying the Alfonsine translation of the treatise preserved, with very few differences, in two texts, the codex Villaamil 156 of the Universidad Complutense (Figs. 1, 2 and 3) and the Escorial manuscript. But a comparison with the chapter on the description (by 'Ali b. Khalaf) and the chapters dedicated to the construction of the instrument (by Rabiçag) shows some inconsistencies. Furthermore, to determine reliably the position of some of the elements on the plate, it is necessary to analyse the chapters in the treatise on the use of the plate, and neither Rabiçag nor the illustrator seem to have done so.

Therefore, we have decided to start our study at the very beginning, reviewing all the previous reports, and presenting new data which has gone unnoticed so far. We present the characteristics of the instrument according to the chapter containing the description of the instrument, and taking into account the ways in which it was to be used, as described in the treatise $^{5}$. We have also considered Rabiçag's treatise on the construction. Figures 5 to 10 include our proposal of reconstruction and use of the plate $^{6}$.

These texts are introduced throughout the paper to illustrate our commentaries. The texts corresponding to Rabiçag's treatise on the construction are presented in italics, in order to distinguish them clearly from the passages from 'Alī ibn Khalaf's treatise on the use.

We have followed the standard rules for the edition of Medieval Spanish texts (Blecua, 1983). We have standardised the phonemes, regardless of their different graphic realisations. The alternations $\mathrm{v} / \mathrm{b}$ and $\mathrm{m} / \mathrm{n}$, the graphic cultisms as well as the division of words have been maintained as they appear in the manuscript. The abbreviations have been written out in full without specific indication in the text. The orthographic punctuation has been modified in order to make the explanations clearer.

\section{The author: ${ }^{\mathrm{c} A l i ̄}$ b. Khalaf}

Very little is known about 'Alī ibn Khalaf (Puig 2004). His complete name was Abū l-Hasan Ibn Ahmar al-Ṣaydalānī. He lived in Toledo in the $5^{\text {th }} /$ $11^{\text {th }}$ century where he was a renowned geometer. He is mentioned by Șa ${ }^{\mathrm{e}} \mathrm{id}$ as a member of a group of young philosophers (Șāeid, p. 180), and he has

\footnotetext{
${ }^{5}$ We are planning a new edition of the complete treatise, together with the study of the use of the instrument.

${ }^{6}$ We want to acknowledge the colaboration of X. Crous in the drawing of the figures.
} 
also been identified as the botanist 'Alī al-Shajjar. In the MS Leiden Universiteitsbibliothek 468 he is named as 'Alī b. Khalaf Ahmar Akhyar (or Akhir); this source attributes to him the construction of a universal instrument called al-așturlāb al-ma'mūnì devoted to al-Ma'mūn, amìr of Toledo, in the year $464 \mathrm{BC} / 1071 \mathrm{AD}$ (King 1979). He has also been identified as a certain 'Alī al-Shajjār who appears in a list of astronomers in the $z \bar{l} j$ of Ibn Ishāa al-Tūnisī, $13^{\text {th }}$ C (MS Hyderabad Andra Pradesh 298). According to this source, he made an observation of the obliquity of the ecliptic in Toledo in 477/1084-85 with the assistance of the physician, pharmacologist and botanist Ibn Wāfid. However, bearing in mind the date of Ibn Wăfid's death, $1075 \mathrm{AD}$, a revision to the date of the observation, and even to the whole story, has been suggested (Samsó 1992, p. 181).

\section{The text: the Alfonsine treatise}

As stated above, the lámina universal is only known thanks to the Alfonsine Libros del Saber de Astronomia. There is a non-critical edition by Rico y Sinobas (Rico, vol. III, pp. 1-132) though its reliability has been questioned. We used the facsimilar edition of the codex Villaamil 156 of the Library of the Universidad Complutense in Madrid. The treatise on the construction of the instrument comprises folios $83 \mathrm{v}-87 \mathrm{r}$, and the treatise on the use folios $87 \mathrm{r}-109 \mathrm{r}$. On fols. $84 \mathrm{v}, 85 \mathrm{v}$ and $86 \mathrm{v}$ we find the illustrations which are reproduced with some differences in Rico's edition (Fig. 4).

The reading of the codex reveals that it is, indeed, a translation of an Arabic text. The expressions, syntax, and the technical vocabulary incorporated demonstrate an extreme fidelity to an Arabic original?

The systematic comparison with Rico's edition indicates that his edition was quite faithful to the Alfonsine text. Possibly, from the linguistic point of view, the edition may be criticised for giving a more archaistic patina of what is perceived from the direct reading of the codex. Some omissions in Rico that are already in the royal codex could indicate that the king's collaborators translated a faulty copy of the Arabic original. For example, the beginning of the foreword of the treatise on the use, "Dixo Alin fijo de Halaf", could be due either to the Alfonsine translators or to an Arab copyist. It does not seem to have been translated from an autograph text, because the author of a treatise does not usually refer to

\footnotetext{
${ }^{7}$ On the literal nature of the Alfonsine translations, see Millás Vallicrosa, 1949.
} 
himself in the third person. However, this foreword provides us with some useful information. From it we know:

a) That the text was dedicated to al-Ma'mūn:

Dixo Aly el fijo de Halaf: Loor sea dado a dios, que dio grand entendimiento all ombre et lo aparto de todas las animalias en saber las sciencias et las sotilezas. Et ell ombre nolo puede complir de loores assi como pertenesçe atal sennor como el. Et con todo esto non deue ell hombre quedar del dar loores cada dia. Et dios de ondra al mio sennor el Rey Meymon pora quien fue fecho este libro.

b) That Ibn Khalaf had read Ptolemy's Planispherium ${ }^{8}$ :

Et sepa el que quisiere aprender algo del que despues que yo ui el libro de Ptholomeo, el que fizo de como se deue allanar la espera, et de como se pueden sennalar linnas en cosa llana que sean semeiantes alas linnas que son sennaladas en la sobrefaz de la espera, et que recudan las linnas que son sennaladas en el llano alo que recuden las linnas que son sennaladas en la sobrefaz de la espera, en todas las maneras de los mouimientos. Et este estrumente es al que dizen astrolabio.

c) That his purpose in devising the universal plate was to have an instrument for all latitudes:

Mays sabida cosa es que este estrumente a mester una lamina a cada ladeza et yo pense de como se puede fazer un estrumente que cumple a todas las ladezas por toller la lazeria de fazer cada ladeza una lamina. Et tanto pense en ello fata que entendi como se puede fazer un estrumente pora toda la tierra que non aya en el mas de una lamina et una red et pusle nombre ell orizon uniuersal et alçelo pora mi sennor el Rey Meymon.

d) That he compiled a treatise on the construction without proofs, which has not been preserved:

Et fiz este libro en que fabla de como se deue fazer de nueuo, menos la prueua de su fecho

${ }^{8}$ The presence of this text was attested in al-Andalus since the time of Maslama. Cf. Vernet-Català, 1965 Kunitzsch-Lorch, 1994 and Kunitzsch, 1994. 
and the existence of which the Alfonsine author of the construction treatise denies (no hizo libro de cómo se deue fazer de nuevo).

e) And that he intended to compile a treatise on the different kinds of projecting the sphere with demonstrations, in which he would include instructions for the projection of the new instrument:

fata que ouiesse uagar de fazer un libro en que fable de quantas maneras se puede allanar la espera con prueuas de geometria sobre cada uno assi como a mester. Et en aquel libro fablare de que manera fue allanada la espera en este estrumente et de como son las prueuas sobrel.

f) To conclude, he announces that this text is divided into seven parts and that the first part consists of thirty chapters:

Et este libro es partido en siete partes et en la primera parte a .XXX. capítulos.

Since the text we have is divided into five parts, the first of which has twelve chapters, we conclude that a part has been lost here, possibly the text on the construction. However, a text on the construction of the instrument divided into thirty chapters would be extremely long. Perhaps the seven books and the thirty chapters of the first of them correspond to the theoretical book mentioned in e). If so, this indicates that the project was already well structured and that, probably, 'Alī b. Khalaf had already begun work on it. To our knowledge, if this book was eventually written, it has not been preserved.

\section{The projection of the instrument}

Like al-Zarqālin's plates, the universal plate is based on the stereographic meridian projection of the sphere. In fact, it is a dual stereographic meridian projection of each celestial hemisphere which superimposes the projection of half of the celestial sphere onto the projection of the other half. Another step is needed: to turn one projection over the other in order to have the names of the zodiacal signs along the same diameter (Puig 1986, p.45).

According to the description, the markings engraved on the mater of the universal plate correspond to the longitudes and latitudes of ecliptic coordinates. The horizontal diameter represents the ecliptic, and the names 
of the zodiacal signs are engraved on the plate. These markings can also be used as representations of the almucantarat and azimuthal circles of horizontal coordinates ${ }^{9}$. The plate is fitted with a rete so that it can be used. It may have included an alidade, or, alternatively, the one on the back may have been used instead (see Appendix 2).

As regards the projection system used on the face and the coordinates that represent the traced lines, we have nothing to add to what previous scholars have said over the years. Though our study is not complete, we can state that there are coincidences in the construction layout (in spite of some errors that would be easy for anyone familiar with the projection to avoid), the description in the treatise on the use and, more importantly, the instructions for handling the instrument.

\section{Description of the instrument}

\subsection{Basic elements}

The instrument is fully described in Chapter 2 of the First Part of the book. The elements mentioned in the text are: the mater, the rete, the alidade, the pin and the horse.

Los nombres deste estrumente son estos: la madre et la red et ell alhidada et la llaue et el cauallo.

There is also a throne with a ring called a colgadero.

Et sale del çerçiello ala parte de Septentrion un pedaço que sobra sobre la madre. Et en aquel pedaço a un forado redondo et parte lo la linna de septentrion por medio. Et en aquel forado an metido un priego que se mueue en el et en esse priego metido un cercello á que dizen colgadero don se cuelga la lamina ${ }^{10}$ pora tomar la altura de guisa que, quando cuelgan la lamina deste colgadero et colgaren plomo en medio del priego, passara el filo do es colgado el plomo por la linna de Septentrion et por la linna de medio dia et non se parte della. Et desta manera se deue prouar si es cierta o non. Et si salir el filo de la linna sobredicha, es la lamina errada et endereça

\footnotetext{
${ }^{9}$ Charette (2003, p. 103) introduces the markings engraved on the plate as a grid of horizontal coordinates that can also be used to represent ecliptic coordinates.

${ }^{10}$ MS. linna
} 
la. Et dizen a este priego et a este cercello el colgadero de la lamina.

We should mention two other elements as well: the cabeçon on the plate itself:

Et en la faz primera sobredicha a un çerco a que dizen el cabeçon.

and the cercello.

\subsection{The cercello}

The cercello is the outer part of the instrument and contains the cabeçon.

Et affuera del un cercello soldado, bien cierto et bien raydo. Et ua cada una de sus fazes en derecho de su compannera.

It is a rim, of the same thickness as the rete, welded to the mater.

Et es tan gordo como la red. Et los cabos deste çercello son dos çercos. Et son echados sobrel çentro de la lamina. Et este cercello es soldado con ella de guisa que semeia todo un cuerpo.

It is divided by four straight lines into four equal quadrants. The lines are named: linna del medio cielo, midheaven, up to the ring, the colgadero, in the northern part; angulo de la tierra, angle of the Earth, down to the bottom, in its southern part; linna de oriente, the eastern line, to the right, and linna de occidente, the western line, to the left. To avoid confusion, note that the denomination of the lines only refers to the short segments which divide the cercello into quadrants.

Et este cercello es partido en quatro partes iguales con quatro linnas derechas. Et la una linna ua a parte de septentrion et la otra que se tiene con ella ua a parte de mediodia. Et dizen ala linna que ua ala parte de Septentrion linna del medio çielo et ala que ua a medio dia, dizen linna dell angulo de la tierra. Et dizen a la una de las dos linnas que fincan, que es ala diestra parte dell ombre que tiene la lamina quando fuere la linna de septentrion fazal medio çielo linna de oriente et ala que es de la parte siniestra linna de occidente. 
Each quadrant of the cercello is divided into 90 equal parts, grouped in quinary sections (cincularios) and numbered from each one of the eastern and western lines up and down to the northern and southern lines. These divisions are also called alhogera in the description, from the Arabic alhujra. This is the well-known graduate limbus which we usually find around the mater of the astrolabe.

Et cada uno de los quatro quartos del cercello ${ }^{11}$ es partido por .XVIII. partes iguales. Et son escriptos en ellas los cuentos que uan de cinco en cinco. Et comiençan en los dos lados de las linnas de oriente et de occidente. Et uan subiendo hata .XC, en los dos lados de las dos linnas del comedio de Septentrion et de medio dia. Et cada una parte destas .XVIII. ${ }^{12}$ es partida por .V. partes iguales. Et desta guisa sera cada uno de los quartos partido por .XC. partes iguales. Et sera todo el cercello ${ }^{13}$ partido por .CCC. et .LX. partes iguales. Et a estas partes dizen en arabigo alhogera.

At this point, the treatise on the use confuses the names cercello and cabeçon: the text says cabeçon instead of cercello (see n. 9 and 11), and the cabeçon is erroneously described as holding the graduation mentioned above which, in the treatise on the construction, is clearly attributed to the cercello:

Faz una lamina de laton amariello bien llana (e)t faz enella un cerco quama(n)no quisieres. Et faz un çerciello que uenga sobrel tal como el que es fecho enell astrolabio. Et sea tan ancho que quepan enel los çercos q(ue) te yo dire adelantre. (e)t sea tan alto como la gordura dela lamina misma (...) (e)t parte el mayor çerco destos tres por [.LXXII.] partes yguales (...) (e)t estos seran los cinculares. Et desi parte cada çinco por çinco partes yguales (...) et desta guisa auras partido el çerco de dentro por .CCC. (e)t.LX. partes $^{14}$.

${ }^{11}$ MS. cabeçon

${ }^{12} \mathrm{MS} . \mathrm{XC}$

${ }^{13}$ MS. Cabeçon

${ }^{14}$ This fragment is in italics because it is taken from Rabiçag's treatise on the construction. 
Clearly, there is a copying or translating error here, because when we use the plate we need the divisions on the cercello, making it irrelevant whether the cabeçon of the mater is divided or not. It seems that the translator's description was rather careless - amateurish even. The drawing of the mater in the manuscript also identifies the cabeçon and the cercello, showing an incomplete drawing of the plate, which does not help to reconstruct the whole instrument (Fig. 1). However, the drawing of the rete in the same manuscript clearly shows a surrounding band (Fig. 2). The drawing in Rico also adds an external empty crown that does not make much sense (Fig. 3), but seems to represent this element.

The four arcs into which the cercello is divided receive the names of: oriental septentrional, north-eastern (between the east line and the north); occidental septentrional, north-western, and also quarto de la altura, quadrant of the height (between the west line and the north); oriental meridional, south-eastern (opposed to the previous one) and occidental meridional, south-western, the one that is opposed to the first one ${ }^{15}$.

Et dizen al quarto que es entre la linna de oriente ${ }^{16}$ et la linna de septentrion oriental septentrional. Et al quarto que es entre la linna de occidente et septentrion, occidental septentrional. Et dizen a este quarto sobredicho entre todos los quartos, el quarto de la altura. Et el quarto que es en so opposito dizen oriental meridional. Et dizen al quarto que finca occidental meridional.

\subsection{The face of the plate ${ }^{17}$ (Fig. 5)}

\subsubsection{The mater}

The mater is the plate engraved on its face with a grid of coordinates and showing the solar calendar on its back:

\footnotetext{
${ }^{15}$ Note that these divisions are only related to the cercello. They have nothing to do with the division into quadrants of the horizontal coordinates (cf. 5.3.4 i). They coincide, though, with the division into quadrants on the back of the instrument (cf. 5.4).

${ }^{16}$ MS. Occidente

${ }^{17}$ The text describes the ecliptical and horizontal coordinates simultaneously, since both can be represented by the same lines. In what follows we have edited the text separating the two descriptions. The jumps are indicated by ellipses (. . .).
} 
Et la madre es la lámina que es sennalada de ambas las partes. Et la una parte es do son las longuras et las ladezas. Et la otra parte do es la iguacion del Sol.

\subsubsection{The cabeçon}

As in the astrolabe plates, the cabeçon is the empty crown, a band, surrounding the projection lines of the plate. In astrolabe treatises this empty crown is not usually mentioned, nor does a name exist for it in the relevant lexicons ${ }^{18}$. It does not usually take graduation because the rete of the astrolabe is superimposed on it. In fact, instead of one cabeçon, this universal plate has two, one in the mater and the other in the rete. The second of these is graduated (see fig. 6). This is clear from the chapters on the use.

\subsubsection{Ecliptical coordinates}

a) The circle inside the cabeçon and with its centre on the centre of the mater is the meridian circle. The horizontal diameter represents either the ecliptic line or the horizon.

Et el çerco que es so centro el de la madre, et es el cabeçon en derredor del, dizen le el çerco de medio dia. Et las dos linnas derechas que se taian sobre angulo derecho en el centro de la madre sabe que se taian dellas la que es en el comedio de los nombres de los signos alas uezes la ponen que es el zodiacho et alas uezes que es ell orizon.

b) If the horizontal diameter is the ecliptic line, then the perpendicular diameter is its polar axis. The north pole of the ecliptic is on the meridian circle, in the part of the colgadero. The south pole is the opposite point, at the bottom of the plate.

Et quando la ponen que es el zodiacho sera la segunda linna que se taia con ella la linna que passa por los dos polos del zodiacho. Et sera el polo septentrional el punto do se taia esta linna sobredicha

${ }^{18}$ Cabeçon, attested for the first time in Spanish circa 1250, and its modern spelling cabezón means "border of a shirt". This meaning matches quite well the empty crown or the band that we propose. Professor Kunitzsch agreed that the word may point in this direction. We are very grateful for his comments on the subject. 
en el çerco de medio dia en la parte del colgadero. Et el polo meridional ${ }^{19}$, el punto do se taia con ella de la otra parte.

c) The equinoctial points coincide at the centre of the mater.

Et dizen al centro de la lamina los dos puntos de las dos igualdades si posieres aquella linna el zodiacho.

in the treatise on the construction:

et seran el començamiento de aries. (e)t de libra en el çentro.

d) The solstitial points are in the intersection between the ecliptic line and the meridian circle. These points are called mudamientos. In the northern hemisphere, the starting point for counting is the winter Solstice of Capricorn.

Mays si lo posieres que sea zodiacho seran estos dos puntos sobredichos ${ }^{20}$ los dos puntos de los mudamientos. Et dizen al que es do se comiençan los cuentos el mudamiento iuernal et all otro el mudamiento uerenal. Et esto es en los logares septentrionales. Mays en los logares meridionales son los nombres el so contrario.

e) The zodiacal line is thus divided into $360^{\circ}$, starting from Capricorn. The figures are written from $5^{\circ}$ to $30^{\circ}$ for each sign.

Et los cuentos que comiençan en la cabeça de capricornio et se allegan hata .CCC. et .LX. et andan por los dos lados de la linna derecha dizen les grados iguales si posieres esta linna sobredicha por zodiacho. Et los cuentos que uan de .XXX et .XXX. cada .XXX. dellos en derecho de un signo dizen a cada .XXX. dellos grados daquel signo so que son escriptos.

f) Above these divisions the names of the zodiacal signs are written. According to the description, the signs between Capricorn and Gemini are called signs of ver (or verenal), and those from Cancer to Sagittarius are called signs of autuno (or autumnal). The signs between the first of Aries

\footnotetext{
${ }^{19}$ MS. adds et

${ }^{20}$ Cf. $\left.5.3 .4, b\right)$
} 
and the end of Virgo are northern, and those between the first of Libra and the end of Pisces are southern.

Et los signos que son del començamiento de Capricornio fata la fin de Gemini segund uan por orden dizen les los signos de uere. Et los signos que son del començamiento de Cancer fata la fin de Sagitario dizen les signos de autuno (...) Et los signos que son del començamiento de Aries fata la fin de Uirgo segund uan por orden son los signos septentrionales et los que uan del començamiento de Libra fata la fin de Pisces son los signos meridionales.

But where is Capricorn? The drawing of the plate in the manuscript and in Rico's edition, following the instructions in Rabiçag's treatise on the construction, places Capricorn to the left (sobrel punto de $b$ ala tu siniestra parte) and above the horizontal diameter of the plate in such a way that the signs go from left to right.

Et escriue las.XII. figuras de ambas las cuestas de la linna de .d.b. et las seys sean de suso et las seys de yuso.Et comiença de escreuir de la mano derecha de yuso de la linna de d.b. el signo de cancer et el de leo et el de virgo. Et esto sera do es el çentro de la lamina. Et escreuiras despues libra et escorpio (e)t sagitario. Et aqui te allegaras al çerco de la lamina. Et desi escriue los otros seys signos de suso de la linna de d.b. començando de la mano esquierda (e)t yendo ala derecha. Et comença de escreuir en capricornio et en aquario (e)t en piscis. (E)t aqui allegaras al çentro de la lamina. Et escreuiras despues. aries, tauro (e)t gemini. Et seran el començamiento de aries (e)t de libra en el centro et el començamiento de cancer sobrel punto de .d. ala tu diestra parte et el començamiento de capricornio sobrel punto de.$b^{21}{ }^{21}$ ala tu siniestra parte.

From the way the plate must have been used we deduce that Capricorn should be to the right, and so the signs would follow from right to left. This can also be inferred from some of the chapters in which, as a first step, the coordinates of the rete must be correctly placed over the mater (see Appendix 1 and Fig. $8^{22}$ ). Furthermore, because of the direction of the

\footnotetext{
${ }^{21}$ MS. D

${ }^{22}$ Fig. 8 shows the equator and the ecliptic at an angle of $23 ; 30^{\circ}$ with Capricorn and the signs between the first of Libra to the end of Pisces in the southern hemisphere, as has been said.
} 
writing (from right to left), this would be the standard arrangement on an Arabic instrument.

Since in the description of the instrument the position of Capricorn is not specified, we wonder whether a latent question of laterality might have led the Alfonsine author of the treatise of construction of the plate to place Capricorn in a pre-eminent place on the left-hand side.

g) The plate is divided into four quadrants

Et segund que auemos dicho fata aqui, parte se el çerco de los signos et los grados iguales et las pieças de las ladezas et de las longuras por quatro ${ }^{23}$ partes iguales. La primera parte dellas es la que cae entre las dos linnas que salen del centro et ua la una al mudamiento iuernal et la otra al polo septentrional. Et dizen le uerenal meridional. La segunda parte es la que cae entre las dos linnas que salen del centro et ua la una al mudamiento uerenal et la otra al polo septentrional. Et dizen le uerenal septentrional.Et dizen a la parte que es en opposito de la primera parte autunal septentrional et a la parte que es en opposito de la segunda. autunal meridional. Et esto es en los logares septentrionales. Mays en los logares meridionales mudasse uer por autuno et autuno por uer et dizen autuno en los logares meridionales al quarto al que llaman uer en los logares septentrionales et dizen uer en estos logares sobredichos alo que llaman en los otros logares autuno.

h) The circular arcs which meet at the poles are the cercos de la ladeza (great circles of longitude). The circular arcs which are perpendicular to them are called cercos de la longura (small circles of latitude). Both the ones between the Zodiac and the northern pole are northern, and the ones between the Zodiac and the southern pole are southern.

Et dizen a las pieças de los çercos que passan por los dos polos los çercos de la ladeza. si posieres la linna sobredicha que sea zodiacho et alas otras pieças de los çercos que se taian con ellas çercos de la longura. Et dizen alas pieças de los çercos de la ladeza et a las pieças de los çercos de la longura que son entre el zodiacho et entrel polo septentrional ladezas et longuras septentrionales. Et lo que fuere dellas entrel zodiacho et el polo meridional dizen les ladezas et longuras meridionales.

\footnotetext{
${ }^{23}$ MS. it. quatro
} 


\subsubsection{Horizontal coordinates}

a) The horizontal diameter can also be taken as the horizon. In this case, the vertical diameter is its polar axis, as well as the east-west line (linia de medios orientes et occidentes). The zenith will coincide with the northern pole if the latitude is northern, and with the southern pole if the latitude is southern.

Et quando posieren la linna sobredicha por orizon a qual logar quier, sera la segunda linna que se taia con ella la linna que passa por los dos polos daquell orizon et dizen le la linna que passa por los medios orientes et los occidentes. Et si fuer la ladeza daquel logar septentrional, sera el punto do es el polo septentrional zonte de la cabeça daquel logar. Et si fuere su ladeza meridional, sera el punto do es el polo meridional el zonte de la cabeça daquel logar.

b) The centre of the mater is the EW point (comedio de los orientes et de los ponientes).

Et si la posieres orizon. Sera aquel punto el comedio de los orientes et de los ponientes.

c) The intersection between the horizon and the meridian circle occurs at the points of comedio de mediodia (beginning of Capricorn) and comedio de septentrion (beginning of Cancer). According to the comments above, the beginning of Capricorn would be on the right-hand side.

Et dizen al punto do se taia la linna dell orizon con el çerco de medio dia el comedio de medio dia ${ }^{24}$. Et ell otro punto que es en so opposito el comedio de septentrion. Et esto es en los logares septentrionales. Mays en los logares meridionales es so contrario. Et esto sera si tu posieres la linna sobredicha que es orizon.

d) The arcs of circle which meet at the poles are the cercos de la altura (azimuths) or cercos de los zontes (the literal translation of the Arabic term for them being dawā'ir al-sumūt).

${ }^{24}$ MS. adds de me 
Et si posieres la linna sobredicha que sea orizon diran a aquellas pieças sobredichas que passan por los dos polos çercos de la altura. Et dizen les otrossi çercos de los zontes.

e) The circular arcs which are perpendicular to them are called empontizos (the literal translation of the Arabic term for them being al-muqanțarāt).

Et dizen alas piezas de los çercos que se taian con los çercos de la altura los enpontizos. Et dizen les en arabigo almucanrath.

f) In both cases the arcs between the horizon and the northern pole are northern, and those between the horizon and the southern pole are southern.

Et las ${ }^{25}$ pieças que cayeren en la parte de Septentrion dell orizon son zontes et empontizos a los logares que son sus ladezas septentrionales. Et lo que cayer dellas en la parte de medio dia seran zontes et enpontizos alos logares que son sus ladezas meridionales.

g) When the horizontal diameter corresponds to the horizon, the divisions on it correspond to the azimuthal divisions (cuentos de los zontes).

Et si posieres esta linna por orizon seran los cuentos que comiençan del comedio de medio dia et uan fata .CCC. et.LX. et andan en anbos los lados desta linna sobredicha dizen les los cuentos de los zontes. Et $\{$ los $\}$ cuentos que son entrell orizon et entrel polo septentrional dizen les las partes de los zontes orientales. Et los cuentos que son entrell orizon et entrel polo meridional son partes de los zontes occidentales.

h) The circles between the centre and the comedio de septentrion up and down half of the horizontal line are called zontes septentrionales and zontes meridionales.

Et otrossi si possieres esta linna por orizon seran las partes de los zontes et las pieças de sos çercos et los enpontizos que caen sobre los dos lados del medio desta linna. los que comiençan del centro de la madre et allegan se fatal comedio de Septentrion las partes de los zontes septentrionales. Et las pieças de los çercos de los zontes

${ }^{25}$ MS. alas 
septentrionales et los enpontizos septentrionales et las partes que cayeren en los dos lados de la otra meatad desta linna et las pieças de los çercos de los zontes et de los enpontizos que son otrossi sobre sus lados son partes de los zontes meridionales et los enpontizos meridionales.

i) In this way, the plate is divided into four quadrants.

Et con esto son las partes de los çercos zontes et las pieças de los çercos de los zontes et los enpontizos cada uno dellos partido por quatro partes iguales. La primera parte es la que cae entre las dos linnas que salen del centro et allega se la una fatal comedio del medio dia et la otra fatal punto del zonte del medio de la cabeça de los septentrionales. Et dizen a esta parte en los logares septentrionales oriental meridional. Et la segunda parte es la que cae entre las dos linnas que salen del centro et allega se la una fatal comedio de Septentrion et la otra fatal zonte de la cabeça de los septentrionales. Et dizen a esta parte en los logares septentrionales oriental septentrional. Et dizen a la parte que es en opposito de la primera parte en los logares septentrionales occidental septentrional. Et dizen a la segunda parte en los logares septentrionales occidental meridional.

j) There are indications on the differences in the southern latitudes:

Et mudan se los nombres destos quartos en los logares meridionales, assi como el quarto a que dizen en los logares septentrionales oriental meridional. Et dizen en los logares meridionales occidental septentrional. Et desta manera se mudan los nombres de los otros quartos.

\subsection{The back of the plate (Fig. 3)}

The back of the plate is called the face of the Sun's equation (faz de la iguacion del $\mathrm{Sol}$ ) and the elements are similar to the ones found on the back of a conventional astrolabe. It is divided by the two perpendicular diameters into four equal parts.

Et ala segunda faz de la lamina dizen la faz de la iguacion del Sol. Et a en ella dos linnas que se taian sobre angulo derecho sobrel centro de la $[/ / 88 \mathrm{v}]$ lamina et parten la por quatro partes iguales. 
The vertical diameter corresponds to the line that is called linna de septentrion et de medio dia on the cercello of the plate, which is the northsouth line. The horizontal diameter is the east-west line.

La una linna es la que passa por medio del colgadero. Et uiene en par de la linna a que dizen en la faz del cabeçon linna de septentrion et de medio dia. Et dizen a la linna que uiene del colgadero et se allega fatal centro, linna del medio çielo et linna del comedio de septentrion. Et dizen alo que finca desta linna en la otra parte, linna dell angulo de la tierra et linna del comedio de medio dia. Et dizen ala otra linna que se taia con ella, linna de comedio de oriente et de occidente. Et lo que cayer desta linna a diestro del que catare en esta lamina seyendo el colgadero en la parte de suso, linna del medio de oriente. Et lo que cayer della a so siniestro dizen le linna del comedio de occidente. Et cada uno destos quartos sobredichos es partido assi como los otros quartos que son en la primera faz et escriptos assi como son aquellos escriptos en el cercello ${ }^{26}$. Et dizen al quarto que es entre la linna del comedio de oriente et la linna del comedio de Septentrion, oriental septentrional. Et al quarto que es entre la linna del comedio de occidente et la linna del comedio de Septentrion dizen occidental septentrional. Et dizen a este quarto sobredicho entre los otros, quarto de la altura. Et dizen al quarto que es en opposito deste quarto sobredicho oriental meridional. Et all otro quarto que finca occidental meridional.

The outer scales of the two upper and lower quadrants are labelled altitude scales with arguments beginning at the horizontal diameter.

\subsubsection{The circle of the zodiacal signs and their divisions}

This is a concentric circle divided into $360^{\circ}$. These divisions are grouped in groups of $30^{\circ}$ corresponding to each sign. The name of the signs is written below.

Et esta faz sobredicha a dos çercos de la iguacion del Sol. Ell uno es el que sigue ${ }^{27}$ alos quartos sobredichos et el so centro es el centro de la lamina. Et es partido por .CCC. et .LX. partes iguales lo que es cuento de los grados del zodiacho. Et son escriptos de

\footnotetext{
${ }^{26}$ MS cabeçon

${ }^{27}$ MS signe
} 
yuso dellas los cuentos de los grados de cada uno de los signos que uan de .XXX. En .XXX. Et de yuso de cada .XXX. es escripto el nombre de so signo.

\subsubsection{The circle of the months and the days}

This is an eccentric circle divided into 365 parts corresponding to the days of the Julian calendar. Below it, we find the number of the days that correspond to each Julian month.

Et el segundo cerco es deyuso de los signos et es el so centro fuera del centro de la lamina et es partido por .CCC. et .LXV. partes segund que ua el cuento de los dias de los annos romanos. Et deyuso dell es escripto el cuento de los dias de cada mes romano.

\subsubsection{The shadow square}

Inside the solar calendar, in the lower right quadrant, there is a shadowsquare with divisions for each unit into 12 units, corresponding to the extended shadow (sombra espandida, al-zill al-mabsüț) and the conversed shadow (sombra retornada, al-zill al-mankūs) ${ }^{28}$.

Et entre la linna del comedio de oriente et la linna del comedio de medio dia a un quadrante de linnas iguales sobre angulos derechos. Et las dos linnas dell ${ }^{29}$ son leuantadas sobrestas dos linnas sobredichas. Et ell un angulo dellos es en el centro de la lamina. Et cada una destas dos linnas sobredichas es partida por .XII. partes. Et dizen a cada parte dedo. Et son escriptos sus cuentos sobrellos. Et començaron los de escreuir de la linna del comedio de oriente et de la linna del comedio de medio dia començando de uno et allegando fata .XII. Et dizen a cada una destas dos linnas linna de la sombra. Et dizen a la linna que es leuantada sobre la linna del comedio de medio dia linna de la sombra espandida et a la que es leuantada sobre la linna del comedio de oriente dizen le linna de la sombra retornada.

\footnotetext{
${ }^{28}$ Some discrepancies have been noted (see Samsó, 1987, p.41). They will be examined in more detail in later research.

${ }^{29} \mathrm{MS}$ dellas
} 


\subsection{The rete (Fig. 6)}

The rete is engraved on only one of its sides. It is divided into two halves by a horizontal diameter, a straight line called andamio, meridian (from the Arabic mamarr).

Et la red es la lamina cauada sennalada de $\mathrm{la}^{30}$ una faz et es partida sobrel centro con linna derecha por medio (...) Et ell otro medio de la red a en derredor del medio çerco ${ }^{31}$ una linna derecha que passa por el centro de la red. Et dizen a esta linna andamio.

The construction of the rete is described in the second chapter of the treatise on the construction.

Si esto quisieres fazer faz otra lamina llana assí como la primera et faz en ella un çerco que sea tamanno comol çerco de dentro de los tres cercos primeros que oviste sennalados en la primera faz de la lamina sobredicha. Et lima quanto fuer fuera deste çerco, fuera ende quatro cabos que an de sobrar en quatro logares que te yo dite adelantre.

One half of it shows a hollowed-out half set of markings corresponding to the meridians and parallels of declination of equatorial coordinates, and the other half shows a selection of star pointers from the northern and southern hemispheres ${ }^{32}$. This rete must have two or four indexes ${ }^{33}$.

${ }^{30}$ MS written over the line

${ }^{31}$ MS adds et

${ }^{32}$ There is no reference to stars here, but some of them are mentioned in the first chapter of the first part of the treatise on the use. They are buytre cayente: al-nasr al-wāqi, alahabor: al-shi 'rā al- 'abūr, algumeyça: al-gumayșā', alayot: al-'ayyūq, ombro de Gemini: mankib al-jawzā', pie de gemini: rijl al-jawzā', alrramech: al-simak al-rāmih̆, cor de Leon: qalb al-asad, boca del peç meridional: fam al-hūt, cabeça dalgol: rä's al-gül, arridf: al-ridf. The author adds "et las otras estrellas que son puestas en la red" (and other stars that can be found in the rete).

${ }^{33}$ There are two, according to the treatise on the use, and four according to the treatise on the construction. Two indexes seem to be enough (and therefore the correct alternative, see Appendix 1, [2]). 


\subsubsection{The half grid of coordinates}

This half is divided into two quadrants by a radius which represents the equator. Each quadrant is graduated and the graduation is superimposed onto that of the plate. The graduation begins at the equator and reaches 90 degrees at the two ends of the andamio, meridian. These two ends are the called the two poles of the equator. At the two ends of the line of the equator are two indexes (demostradores del comedio de las estrellas).

Et este medio es otrossi partido por medio con una linna derecha que passa por el centro de la red et allega fata el so çerco en el medio do son las estrellas. Et dizen a esta linna la linna dell iguador del dia. Et por esto se faz cada una destas dos partes un quarto de çerco. Et es partido cada uno dellos assi como el cabeçon. Et comiençan de escreuir las cuentas de la linna dell iguador, de .V. fata .XC. et allegan se las dos nouaentenas sobre los cabos dell andamio et en los dos cabos de la linna dell iguador del dia lo que es en la red ay unos annadimientos que sobran demas et dizen les demostradores de los grados. Et los dos puntos que son en los dos cabos de la linna que se taia con la linna sobredicha que es nombrada andamio dizen les los dos polos dell iguador del dia.

Et saca enella dos diametros que se taien sobre angulos derechos enel centro. Et pon sobre los dos cabos dell un diametro a. $\boldsymbol{c}$. $\boldsymbol{E} t$ en ell otro diametro .b.d. Et nombra la linna de a.c. ell andamio mayor. Et dizen all andamio en arauigo almamarr ${ }^{34}$. Et nombra ala linna de .b.d. linna dell iguador del dia. Et faz sobrar de los dos cabos de la linna de a.c. dos pedaços. Et otrosi de la linna .b.d. que anden todauia sobre los grados et sobre los cinculares. Et nombra a estos cabos demostradores et a los dos dell iguador del dia nombralos demostradores del comedio de las estrellas. (...)

Et escriue los cinculares en el çerco desta lamina et comiençalos en los dos cabos de la linna dell iguador del dia que son los dos puntos de .b.d. et allegaran las nouaentenas alos dos puntos de.a.c.

In this half there is also half a system of equatorial coordinates traced according to the same type of stereographic projection as the one used previously in the mater. These coordinates include the madārāt, circulares

\footnotetext{
${ }^{34}$ MS Almanara
} 
or equatorial parallels, and the mamarrät, andamios or equatorial meridians.

Et en este medio a piertegas que se taian unas con otras. Et las que se taian con la linna dell iguador del $\mathrm{dia}^{35}$ dizenles los andamios. Et las sos [// 89r ] oriellas que son de la parte de la sobrefaz deyuso essas son los çercos de los andamios. Et sobrestas oriellas deuen poner las sennales quando quisieren obrar con este estrumente. Et a las otras piertegas que se taian con los andamios dizen les circularios. Et las sus oriellas que son de la parte de la sobrefaz de yuso essas son las pieças de los circularios con que deuen obrar saluo ende ell andamio mediano que es la su oriella con la que deuen obrar una linna derecha que ua por el centro de la red. Et esta es la linna do son los dos demostradores en ambos sus cabos. Et es la linna del iguador del dia. Et sobrestos çercos sobredichos que son fechos de la parte de la sobrefaz deyuso ponen las sennales quando obran con este estrumente. Et el cuento de los allongamientos de los circulares dell iguador del dia son escriptos sobre los dos lados de aqui et de alla. Et sabe que lo que cae de los circularios et de los andamios entrell iguador del dia et entrel so polo septentrional que les dizen circularios et andamios septentrionales. Et los que caen dellos entrell iguador dell dia et entrel so polo meridional dizen los circularios et andamios meridionales.

The text of the construction treatise indicates that care must be taken to pierce out the lower part of these arcs of circles, because this is the edge that will be used when these coordinates are needed. They must be as thin as possible, but must not break:

Et enell un medio desta faz a que cerca archo de a.d.c. et linna de .a.c. sennalaras los circulares a que dizen en arabigo madaharat et los [anda]mios a que dizen en arabigo mamarrat. [et ay]untarsan los andamios en los dos puntos de a.c. et que non passen desta linna de .a.c. a la otra parte. Et los circulares sean medios circularios. Et el cabo de cada uno dellos. en ${ }^{36}$ el archo de .a.d.c. et ell otro cabo sobre la linna de a.c. Et abre este medio sobredicho de guissa que finquen las sobrefazes deyuso de los çercos bien ciertos, ca con essas as de obrar, et tuelle todo lo al.

\footnotetext{
${ }^{35}$ MS adds et

${ }^{36} \mathrm{MS}$ Et
} 
Et fincaran como piertegas que se taian unas con otras. Et lexa las mas delgadas que podieres et de guissa que se non corrompan.

Et el segundo medio desta faz al que cerca archo de a.b.c. et linna de .a.c. sennalaras çercos de longura et çercos de ladeza. Et los çercos de la longura son tales como los circulares que comiençan de un cincular et fenecen en otro cincular so compannero aderredor del punto de .b. et taian todos ala linna de .b.d. la que es linna dell iguador del dia et fenezense y et non salen ala otra parte. Et los çercos de la ladeza son tales como los çercos de los andamios, mays son medios et comiençanse todos en el punto de .b. et taianse con la linna de a.c. et no la passan.

Some instructions are also given on how to use the coordinate set together with the mater of the instrument, since we only have one half and need to put it over either one half of the plate or the other, depending on the hemisphere in which the plate is to be used.

Et sabe que los dos polos dell iguador del dia no an nombres propios, que a horas torna el polo dell iguador del dia el septentrional meridional et el meridional septentrional. Et esto se faze por el poner de los demostradores en los grados de la alhogera. que quando posieres qual quier dellos en qual quarto oriental quier et en qual logar quier del, fazer sa ell un polo de la red en el medio del çerco del medio dia de la madre el que es en so comedio el polo septentrional et ell otro polo en ell otro medio el que es en so comedio el polo meridional. Et si posieres ell otro demostrador en qual quarto quier destos dos sobredichos, tornar sa el polo de la red el que fue en el medio cerco del medio dia de la madre el que es en so comedio el polo septentrional quando posiste el demostrador primero enell un quarto de los dos sobredichos enel medio çerco del medio dia de la madre el que es en so comedio el polo meridional. Et el polo que fue en el medio, el que es en so comedio el polo meridional tornar sa enell otro medio el que es en so comedio el polo septentrional. Et por esto se torna el polo septentrional dell iguador del dia meridional et el meridional septentrional. Et si qual quier de los dos polos dell iguador del dia de los que son en la red cayer en qual medio quier del çerco del medio dia de la madre nombran le con el nombre del polo de la madre que es en aquel medio.

The author stresses the distinctions between the andamios and the çercos de los andamios and between the circularios and the pieças de los circularios. In both cases the second element is described as the oriellas 
que son de la parte de la sobrefaz de yuso which means that, since the instrument has to be engraved and then carved on a metallic plate, the process requires a great deal of skill: the carved meridians and parallels must be very thin but must avoid the risk of breaking. Afterwards, we have to determine which of the two edges corresponds to the graduated meridian or parallel. From the indication it seems that the edge chosen is the lower one.

\subsubsection{The star pointers}

This second half of the rete bears some stars with the names written beside them. Together with the name there is an inscription which indicates whether the star declination is northern or southern, and whether its longitude corresponds to the autumnal or the vernal half of the Zodiac.

Et en la una meatat son puestas las estrellas. Et el nombre de cada una escripto sobrella. Et con el nombre ay dos sennales. Et son o .s.a. o .s.f. o .c.a. o .c.f. Et la estrella que tiene sennal de .s.a. demuestra que es su ladeza septentrional del zodiacho et el so grado de la su longura es en los signos que son enel par de ver. Et la que tiene sennal de .s.f. demuestra que es su ladeza septentrional et el grado de su longura es en los signos que son enel par de autuno. Et la que tiene .c.a. demuestra que es su ladeza meridional et el grado de su longura es en los signos que son enel par de ver. Et las que han .c.f. demuestra que es su ladeza meridional et el grado de su longura es en los signos que son enel par de autuno. Et las estrellas son los cabos agudos que salen en la red.

These stars bear two letters which may be either s.a. or s.f. or c.a. or c.f. depending on whether they are northern (s. from the Arabic shimāl, north) or southern from the ecliptic (c. from $j a n \bar{u} b$, south) and whether their longitude is between the beginning of Capricorn and the end of Gemini, i. e. the part comprising the vernal equinox (a. probably from $r a b \vec{\imath}$, spring) ${ }^{37}$ or between the beginning of Cancer and the end of Sagittarius i.e. the part comprising the autumnal equinox (f. from jarif, autumn). The choice of these letters is interesting, because they provide further support for the notion that this introduction is Arabic in origin.

${ }^{37}$ In the Andalusí dialect the phoneme eayn often sounds /a /. This may account for the use of letter $a$ for rabï. 
The treatise on the construction uses the same two letters to identify each star.

Et despues toma de las estrellas fixas las que son en el primero officio et de las que son en el segundo et sabe la longura de cada una dellas a to tiempo et so ladeza et so parte. Et cata quantas fueren dellas del començamiento de cancer fata la fin de sagitario et nombra las autunales porque cae el punto de autuno en medio. Et quantas fueren dellas entrel compeçamiento de capricornio et la fin de geminis nombra las uerenales porque cae el punto de uer que es cabeça de aries en medio. Et la de que fuer la ladeza septentrional. Faz le sennal de .s. Et la de que fuere la [lade]za meridional faz le sennal de .c. Et ala sennal [de uer] a. Et ala sennal de auptuno .f. Et la estrella que fuer septentrional autunal escriue sobrella .s.f. Et si fuer meridional uerenal escriue .c.a. . Et si fuer meridional autunal escriue .c.f.

The method used to construct this half of the rete is described in great detail. It consists, first, of tracing one half of an ecliptical coordinate system according to the meridian stereographic projection used in the mater in order to place on it the stars previously chosen according to their ecliptic longitudes and latitudes.

The treatise on the construction gives the order of the signs, saying that they are placed in the same way as on the mater.

Next the text says that all these drawings, that are represented as dotted lines in fig. 7, have to be made in such a way that they can be eliminated (the Alfonsine text uses the verbs amatar, toller) after the stars have been put in place. The reason is that only the indexes of the stars must remain. So the rete is pierced out, leaving only the needles of the stars at the points where their position in longitude and latitude has been determined.

The northern stars are placed according to their ecliptic coordinates.

Et desi cuenta la linna de a.c. es el zodiacho. Et pon .d. que es el demostrador del medio de las estrellas ala parte del medio cielo. Et fazersa el punto de .c. ala tu diestra parte. Et el punto de .a. a la siniestra. Et escriue los signos de las dos cuestas de la linna de a.c. Et comença en la parte de suso ala tu siniestra parte en capricornio. Et vernas escriuiendo faz a la tu diestra parte faz a la fin de gemini. Et comiença en la parte de yuso ala tu diestra parte en cançer. Et uernas escriuiendo faz a la tu siniestra parte assi como la sennalaste en la madre. Et escriuelo de guissa que lo 
puedas amatar. Et sennala las estrellas que an la ladeza septentrional en este medio de las estrellas fixas. Et estando la lamina en este estado que te dixe. Et pon cada una de las estrellas en so signo por su longura et su ladeza. Et guardate en la cuenta de los grados de los signos que los tomes assi como uan escriptos por orden.

Once the northern stars have been introduced, the instructions are to substitute the zodiacal signs with their opposites in order to place the southern stars in the same half of the rete following the same procedure. Finally, this half of the rete is pierced out, leaving only the indexes of the stars. The precise instructions are to rotate the rete and to put the "demostrador del medio de las estrellas" in the lower part, and to write the names of the zodiacal signs again. In this second case, each name will be 180 degrees from its first situation. The southern stars are then placed in this same half of the rete according to their ecliptic longitude and latitude. Finally the inscriptions corresponding to the stars are added and the rete is pierced out, leaving only the indexes of the stars.

Et quando acabares las estrellas septentrionales, tuelle la escriptura de los signos et [re]uelue la red et torna al punto de.d. que es [demostrador] del medio de las estrellas, [aparte] dell angulo de la tierra. Et fazersa el punto de .a. [a tu diestra] et el punto de .c. a tu [siniestra]. Et escriue los signos otra uez en [las dos cuestas] de la linna de .a.c. assi como los escreuiste de primero. Et despues sennala las estrellas meridionales cada una en su signo por su longura et por su ladeza, assi como sennaleste las estrellas septentrionales. Et quando las ouieres sennaladas escriue sobre cada estrella su nombre et su sennal que son .s.a.o.s.f.o.c.a.o.c.f. et faz que sea la escriptura de las estrellas septentrionales sennalada de las meridionales. Et despues torna et abre la red assi como se abre la dell astrolabio et pon el cabo de la estrella como un punto agudo. Et esta es la figura de la red.

One of us (Calvo, 2003, p. 37) has pointed out how the shape of this half grid, which is eliminated in the final stage of the instrument's construction (see fig. 7), seems to be identical to the half that appears in some instruments devised in Eastern Islam from the $13^{\text {th }}$ century onwards: the one constructed by Ibn al-Sarrāj (see King 1987 and King 1988), the one from the Lahore School whose rete was auctioned at Christie's in 1995 [and the mater in 2001], and also the ones described by John Blagrave and Charolus Whitell. However we stress that the remaining half of 
coordinates in the universal plate at its later stage is different from all those mentioned above, and it is our opinion that the description found in the Alfonsine treatise on the construction is consistent with the elements described by 'Alī b. Khalaf; if one keeps in mind the treatise on the use, with whose instructions both texts are fully consistent ${ }^{38}$, there is no confusion.

A rete bearing a half-coordinate grid shaped like 'Alī b. Khalaf's original astrolabe can be found in the rūmī astrolabe described by Najm al-Dīn al-Mișrī (Charette 2003, p. 105).

\subsection{Alidade}

As in the astrolabe, the instrument is completed with an alidade, a pin, and a horse.

Et ell alhidada desta lamina es tal como ell astrolabio. Et el priego que entra en la lamina et en la red es tal como el priego dell astrolabio. Et el cauallo que tiene la lamina con la red es tal como el dell astrolabio.

\section{Concluding remarks}

To sum up the article's main findings:

1) With regard to the projection system used on the face and the coordinates represented by the traced lines, there is nothing to add to what previous scholars have said. There are coincidences in the construction layout, the description in the treatise on the use and the instructions for handling the instrument.

2) What is new is our proposed correction for the disposition of the signs along the ecliptic. We think that they should be arranged from right to left, with Capricorn to the right, even though this goes against the specifications of the Alfonsine treatise on the construction and the illustrations included in the manuscript as well as in the edition of Rico y Sinobas. We take the use of the instrument as a basis for our proposal, since the description there does not specify the disposition. But would an

\footnotetext{
${ }^{38}$ This includes the Spanish astrolabe described in Moreno et alt. 2002.
} 
Arab author beginning to compute right ascensions from Capricorn have any choice but to locate it to the right?

3) We detect certain confusion between the cercello and the cabeçon. The cercello (al-huŷra) is the graduated limb that we usually find around the mater of the astrolabe. The cabeçon is a circular crown that contains the lines of projection of the plate of the astrolabe. The cabeçon does not usually take graduation because the external circle of the rete of the astrolabe is superimposed on it.

The treatise on the construction says nothing about the cabeçon but explains clearly how to divide and to graduate the cercello. In the description of the treatise on the use, nevertheless, nothing is said about the cercello and the cabeçon is mentioned instead; we think the author has confused it with the cercello. In astrolabe treatises this empty crown is not usually mentioned and no name exists for it in the relevant lexicons. It is strange that this description, which seems to be a translation of an Arabic original, should include such a mistake. There is also confusion in some of the chapters examined on the use although, in general, there seems to be a graduated cercello and a cabeçon of the plate which may be graduated or not, and on which the graduated cabeçon of the rete will be superimposed in turn.

4) The rete was particularly difficult to construct, which may explain why the diffusion of the instrument was so limited. In the first place, we should mention the existence of a graduated cabeçon that contains the lines of the projection. Second, we confirm the appearance of the lines that represent the equatorial coordinates as they are displayed in the illustration of the manuscript and in Rico's edition. To do so we base ourselves, once again, on the analysis of some of the chapters on the use. If the disposition had been different, the instrument would not have worked. It remains to be determined whether there would have been two or four indexes and whether the instrument would have had an additional alidade to work with the face and the rete or whether the alidade on the back could be used instead.

5) This summary underlines the importance of consulting the text on the use of the instrument in order to be able to reconstruct its real shape faithfully. 


\section{Appendix 1. Edition and commentary of Chapter 2, Part II}

\section{Cap(itu)lo II. De saber la declinacion de qual grado quier que tanta es dell yguador del dia}

[1] Quando esto quisieres saber pon sennal enel zodiacho en aquel grado assi cuemo es dicho enel capítolo que passó, [2] et despues pon ell uno de los dos demostradores que son en la red sobre la mayor declinacion, que es. XXIII. grados et medio, et ponlo en el quarto que es oriental septentrional del cabeçon. [3] Et despues cata si cayer la sennal so el segundo medio de la red, cata all andamio que passa por aquel grado et faz y sennal en el logar do se ayuntó con la sennal [4] et despues sabe ell allongamiento del circulario que passa por la sennal que tú feziste en ell andamio qué tanto es dell yguador del dia et lo que fuer esso será la declinacion daquel grado dell yguador del dia. [5] Et si non cayer la sennal so el medio sobredicho, pon ell otro demostrador en aquel logar do possiste el primero et obra assí cuemo te mandé en este capítulo et aurás la declinacion.

[6] Et a en este fecho otra carrera et es quando tú possieres el demostrador assí cuemo es dicho, et cayer la sennal so aquel medio, cata aquel circulario que passa por aquel grado qué tanta es su longura dell yguador del dia et essa será su declinacion daquel grado.

Comments: The point is to determine the declination of the degree of the Sun (Fig. 9)

[1] We take the ecliptic longitude of the Sun, which has to be put in the horizontal diameter which is the ecliptic, the zodiac. To do so, we follow the instructions given in the first chapter of this Part II: once we know the degree of the Sun and the sign in which it is, we look for it on the face (in the part of the instrument where the cabeçon is), we follow the great circle of longitude (cerco de la ladeza) that passes by it -one has to remember that the names of the signs are not exactly on the diameter-and we mark the intersection with the horizontal diameter that represents the ecliptic.

[2] We put one of the two demonstrators of the rete (this confirms that there are only two) in the north-eastern quadrant of the cercello according to the maximum declination, $23 ; 30^{\circ}$. The text says cabeçon, but this should be corrected since this division in quadrants on the face, as explained above, corresponds to the division of the cercello, of the limb, 
not of the cabeçon. The north-eastern quadrant is the upper right quadrant when we have the face of the plate before our eyes. In this position, once the ecliptic coordinates and the equatorial ones are placed in relation to each other, it is evident that Capricorn should be located on the diameter to the right of the holder of the plate, contrarily to the specifications in the treatise on the construction; otherwise, Capricorn would be above the equator, in the northern hemisphere.

[3] We check whether the mark falls under the half of the rete that shows the equatorial coordinates (el segundo medio according to the order of description of the treatise; el primer medio corresponds to the half of the rete bearing the stars). We transport the mark to the meridian circle (andamio) that passes by it.

[4] The declination will be the distance between the equator and the parallel (circulario) that passes by the mark.

[5] If the mark does not fall under the half bearing the coordinates, it is necessary to rotate the rete in order to use the second demonstrator found in the opposite end.

[6] The alternative suggests that, once in [3], we look directly for the distance between the equator and the parallel passing by the mark.

In our opinion, this chapter confirms the disposition of the zodiacal signs, from right to left, which we propose in $5.3 .3 \mathrm{f}$ ), as well as the aspect of the arcs of circle that represent the equatorial coordinates. If the rete did not have this form, the instrument could not be used following these instructions, and new ones would have to be proposed.

\section{Appendix 2. Edition and commentary of Chapter 31, Part III.}

\section{Cap(itu)lo XXXI ${ }^{\circ}$. De saber la declinacion del Sol et su parte por la su altura enel medio dia.}

[1] Quando esto quisieres saber pon el demostrador del medio delas piertegas enel quarto oriental septentrional sobre la mayor altura dell yguador del dia en tu villa si fuer su ladeza septentrional, o en el quarto oriental meridional si fuere meridional. [2] Et desi pon el demostrador dell alhidada sobre la altura del Sol enel medio dia enel quarto que es en la 
parte del sol del zonte dela cabeça. [3] Et depues cata sobre qual grado del cabeçon dela red caera su cuesta et essa sera la declinacion del Sol dell yguador del dia en la parte do cayó.

Comments: The point is to determine the declination of the Sun and whether it is positive or negative depending on the meridian altitude (Fig. 10).

[1] First of all, we have to put the index placed in the middle of the rete showing the equatorial coordinates marking the co-latitude of the place (la mayor altura dell yguador del dia en tu villa) in the graduation of the north-eastern quadrant (the graduation of the cercello, of the limb), if the latitude is northern. If the latitude was southern, we would operate in the south-eastern quadrant.

[2] In this same quadrant, in which we find the zenith, (the zonte dela cabeça) we will mark the meridian altitude of the sun. Surprisingly, instead of marking a sign on the graduation of the limb, the instructions propose the use of an alidade.

[3] We follow the border of the alidade towards the centre of the plate, and in the cabeçon of the rete we read the degrees that correspond to the declination of the Sun, which will be northern or southern depending on whether it is above or below the equator. This is one of the few chapters in which an alidade is used. In this case a special alidade is not needed, and the one on the back can be used; since the reading could be carried out in the same way without an alidade, its presence on the face of the instrument does not seem to be indispensable.

This chapter and other similar chapters demonstrate that the cabeçon of the rete is graduated and that it has to be used in conjunction with the cercello in the mater. These characteristics make this instrument completely different from the ones with a rete that have been mentioned in the paper. 


\section{Bibliography}

Blecua, A. 1983. Manual de crítica textual. Madrid

Brockelmann, C. 1937. Geschichte der Arabischen Litteratur, Supplementband. Leiden.

Calvo, E. 1990. La lamina universal de 'Alī b. Jalaf (S. XI) en la versión alfonsí y su evolución en instrumentos posteriores. Ochava Espera y Astrofisica. Barcelona, pp. 221-238.

Calvo, E. 1997. "Ibn al-Zarqālluh", Encyclopaedia of the History of Science, Technology and Medicine in Non-Western Cultures. Kluwer ed. Dordrecht, 415- 416.

Calvo, E. 2003. "La labor de difusión de la cultura árabe por parte de Alfonso X y su contribución a la formación del lenguaje científico. Los Libros del Saber de Astronomía". La Civilización Islámica en Al-Andalus y los aspectos de tolerancia Rabat, pp. 27-42.

Charette, F. 2003. Mathematical Instrumentation in FourteenthCentury Egypt and Syria. The Illustrated Treatise of Najm al-Din al-Mișrī, Leiden-Boston.

Corominas, J. and Pascual, J.A. 1997: Diccionario crítico etimológico castellano e hispánico. $1^{\mathrm{a}}$ ed. $5^{\mathrm{a}}$ reimpr. 6 vol. Ed. Gredos. Madrid.

Gunther, R. 1932. The Astrolabes of the world, 2 vols., Oxford. (Reprinted London, 1976).

King, D.A. 1986. A Survey of the Scientific manuscripts in the Egyptian National Library. Publications of the American Research Center in Egypt. Winona Lake.

King, D.A. 1986. "The Astronomy of Mamluks", Isis, 74 (1983) 531 555, reprinted in Islamic Mathematical Astronomy Variorum Reprints (London) III. 
King, D.A. 1987. "The Astronomical Instruments of Ibn al-Sarraj: A brief Survey", Islamic Astronomical Instruments, Variorum Reprints. London.

King, D.A. 1988. "Universal Solutions to Problems of Spherical Astronomy from Mamluk Egypl and Syria" A Way Prepared. New York, London, pp. 160-163.

King, D.A. 1987. "On the Early History of the Universal Astrolabe in Islamic Astronomy, and the Origin of the Term "Shakkāziyya" in Medieval Scientific Arabic", Journal for the History of Arabic Science, 3 (1979) pp. 244-257, reprinted in Islamic Astronomical Instruments. Variorum Reprints. London.

Kunitzsch, P. 1994. "The Second Arabic Manuscript of Ptolemy's Planispherium". Zeitschrift für Geschichte der Arabisch-Islamischen Wissenschaften , 9, 83-89.

Kunitzsch, P., Lorch, R. 1994. Maslama's Notes on Ptolemy's Planispherium and Related Texts. Bayerische Akademie d. Wissenschaften, Phil.-Hist. Kl. Sitzungsberichte, Jahrg. 1994, Heft 2. Munich.

Michel, H. 1947. Traité de l'Astrolabe. Paris. Repr. Paris, 1976.

Millás Vallicrosa, J.M. 1933. Don Profeit Tibbon Tractat de l'assafea d'Azarquiel. Barcelona.

Millás Vallicrosa, J.M. 1943-50. Estudios sobre Azarquiel, MadridGranada.

Millás Vallicrosa, J.M. 1944. "Un ejemplar de azafea árabe de Azarquiel”, Al-Andalus, 9, pp. 111-119.

Millás Vallicrosa, J.M. 1949. "El literalismo de los traductores de la Corte de Alfonso el Sabio", Estudios sobre Historia de la Ciencia Española, Madrid, pp. 349-358. Repr. 1987.

Moreno, R. et. al. 2002. "A Recently Discovered Sixteenth-Century Spanish Astrolabe", Annals of Science, 59 , 331-362. 
Puig, R. 1985. "Concerning the șafịha shakkāziyya", Zeitschrift fur Geschichte des Arabischen Islamischen Wissenschaften, 2, 123-139.

Puig, R. 1986. Al-šakkāziyya de Ibn Naqqāš al-Zarqālluh. Edición, traducción y estudio. Barcelona.

Puig, R. 1987. "El Taqbīl 'alā risālat al-ṣafịha al-zarqāliyya de Ibn alBannā' de Marrākus", Al-Qanțara, 8, 45-64.

Puig, R. 1987a. Los Tratados de Construcción y Uso de la Azafea de Azarquiel. I.H.A.C. Madrid.

Puig, R. 2003. "Arzachel", Lexikon der bedeutenden Naturwissenschaftler, p. 75.

Puig, R. "Ibn Jalaf Al-Șaydalan̄̄", Biblioteca de al-Andalus, vol. III, pp. 28-29.

Rico y Sinobas, M. 1864. Libros del Saber de Astronomía del Rey D. Alfonso $X$ de Castilla. Compilados, anotados y comentados por... t. III, Madrid, pp. 1-132.

Sāeid Al-Andalusī, Tabaqāt al-Umam- Ed. Ḥayāt Bū 'Alwān. Beirut, 1985. French Trans. R. BLACHERE, Livre des catégories des nations. Paris, 1935. English trans. by Sema'an Salem and Alok Kumar. Austin: University of Texas Press, 1984,1997².

Sarton, G. 1927. Introduction to the History of Science, vol. I, Baltimore.

Samsó, J. 1987. "Sobre el trazado de la azafea y de la lámina universal: intervención de los colaboradores alfonsíes”, Al-Qanțara, 8, pp. 29-43.

Samsó, J. 1992. Las Ciencias de los Antiguos en al-Andalus. Madrid.

Samsó, J. “al- Zarqā̄l̄̄”, EI, XI, 461-462

Sédillot, L.A. 1844. "Mémoire sur les instruments astronomiques des Arabes, Mémoires présentées par divers savants 1'Académie Royale des Inscriptions et Belles Lettres de l'Institut de France", París, reprinted by 
the Institut für Geschichte der Arabisch-Islamischen Wissenschaften. Frankfurt. 1984.

Suter, H. 1900. Die Mathematiker und Astronomen der Araber und ihre Werke, Leipzig.

Vernet, J. “al-Zarqali”, DSB, vol. XIV, pp. 592- 595.

Vernet, J., Català, M.A. 1965. "Las obras matemáticas de Maslama de Madrid" al-Andalus, 30, 16-45. 


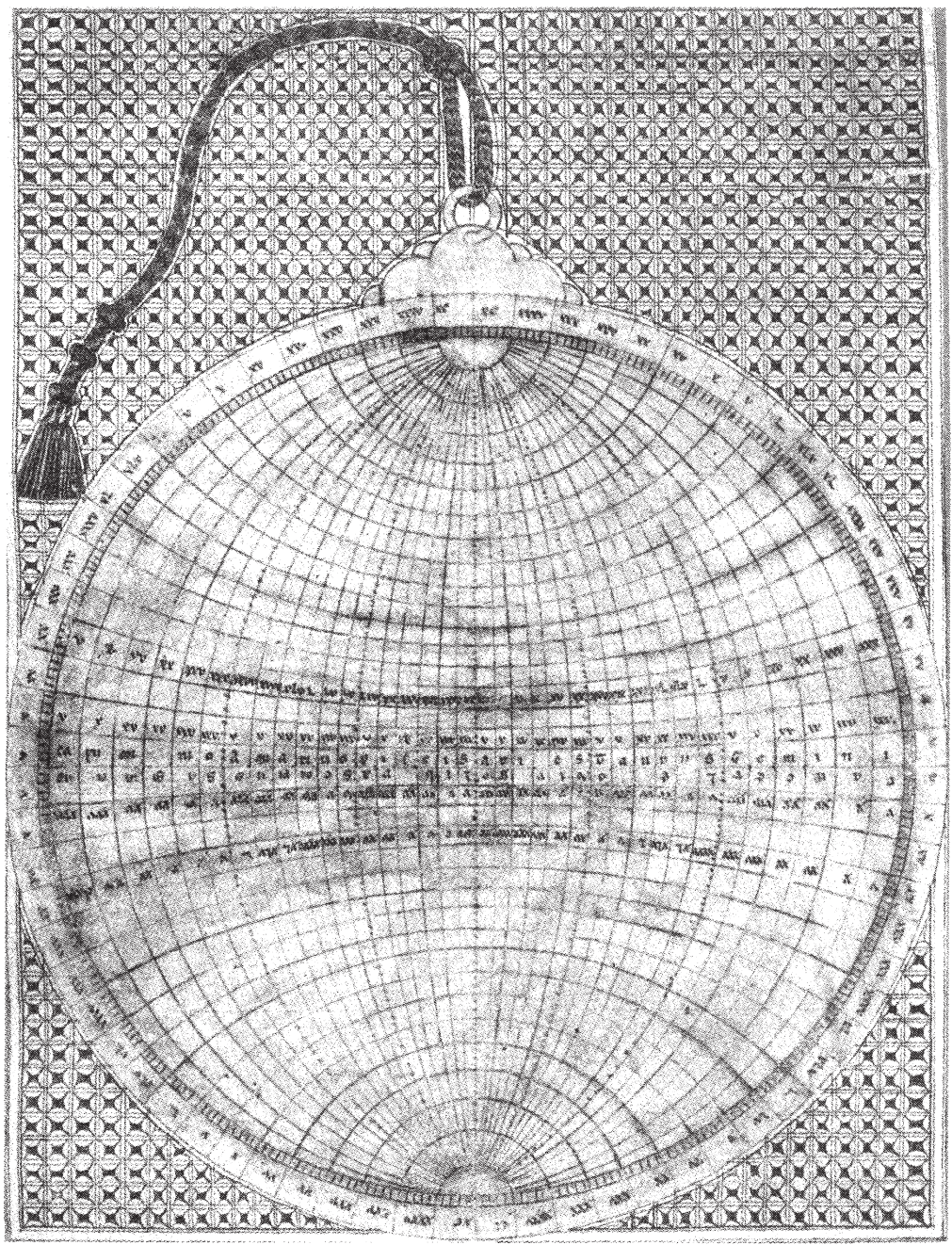

Fig. 1 Face of the Universal Plate. MS Villaamil 156 Library of the Universidad Complutense de Madrid 


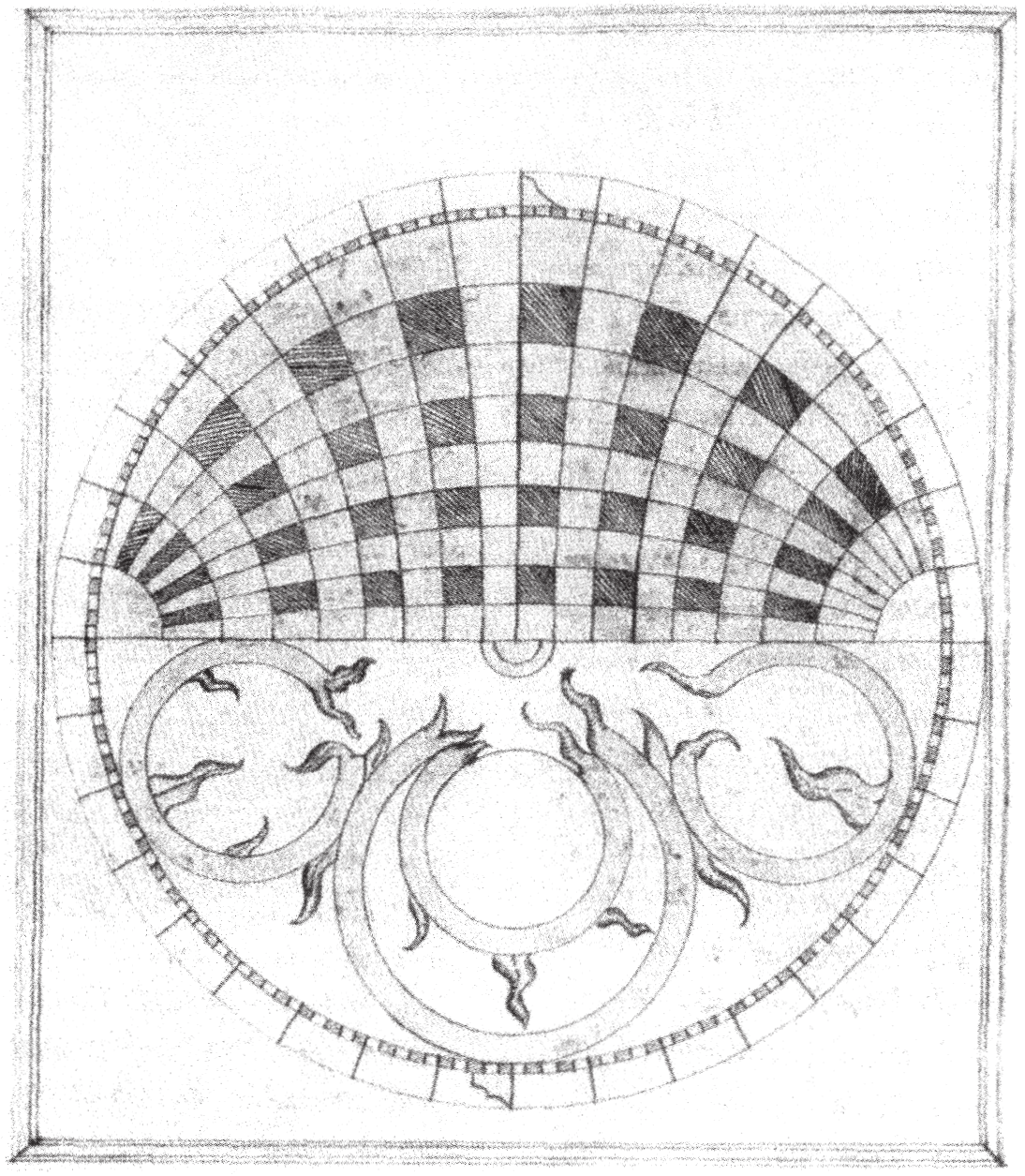

Fig. 2. Rete of the Universal Plate. MS Escorial h I 1 fol 103 v. 


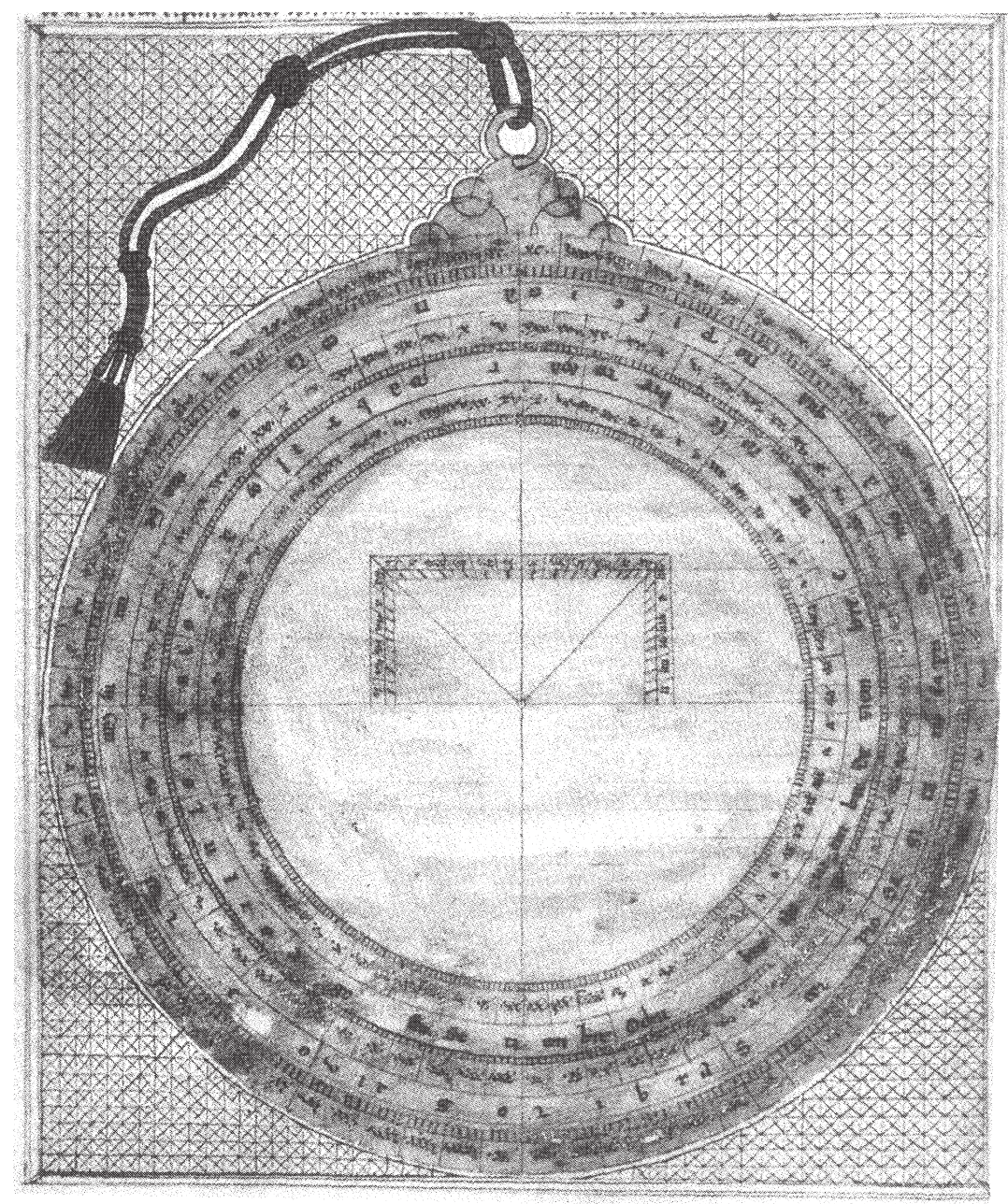

Fig. 3. Back of the Universal Plate. MS Villaamil 156 Library of the Universidad Complutense de Madrid 


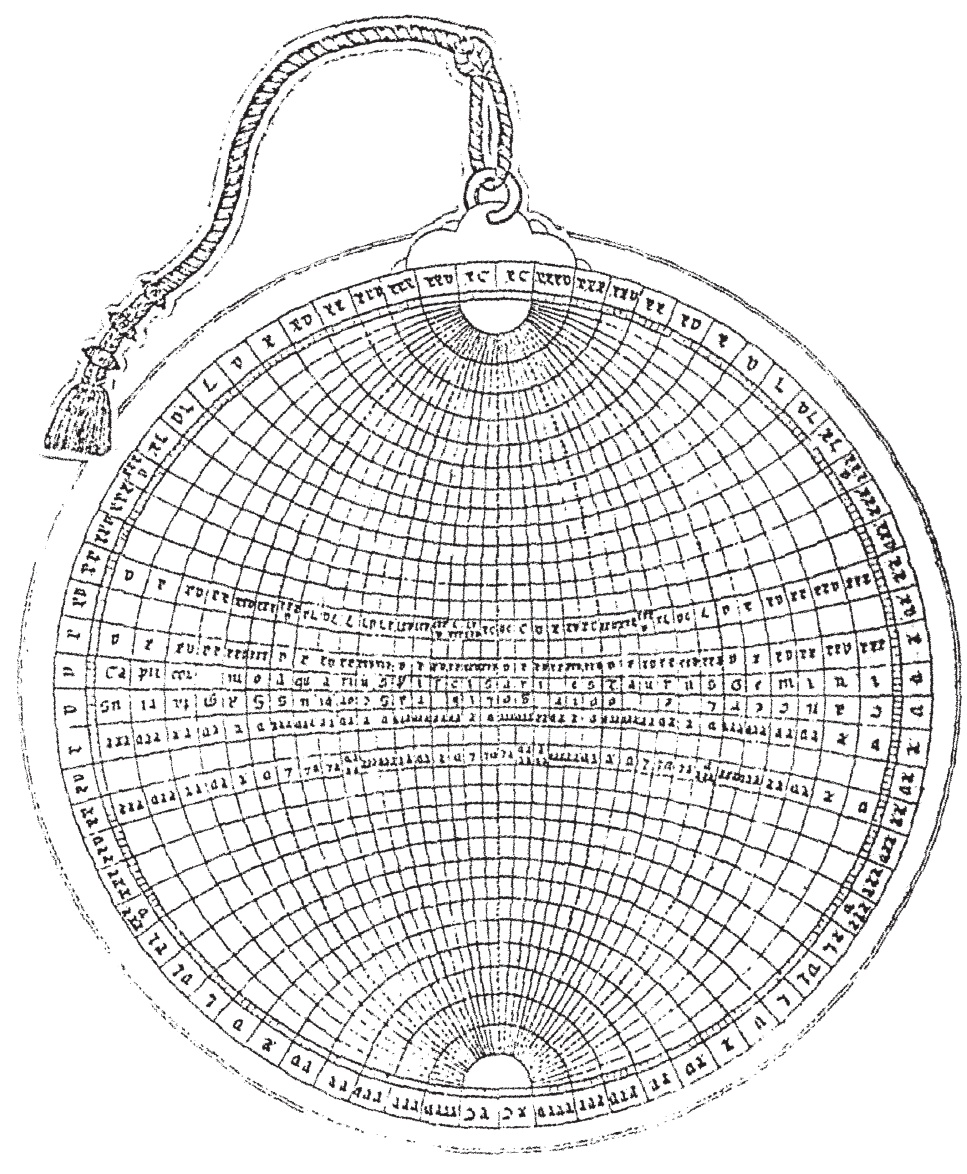

Fig. 4 Face of the Universal Plate

Rico's edition of the Libros del Saber de Astronomia 


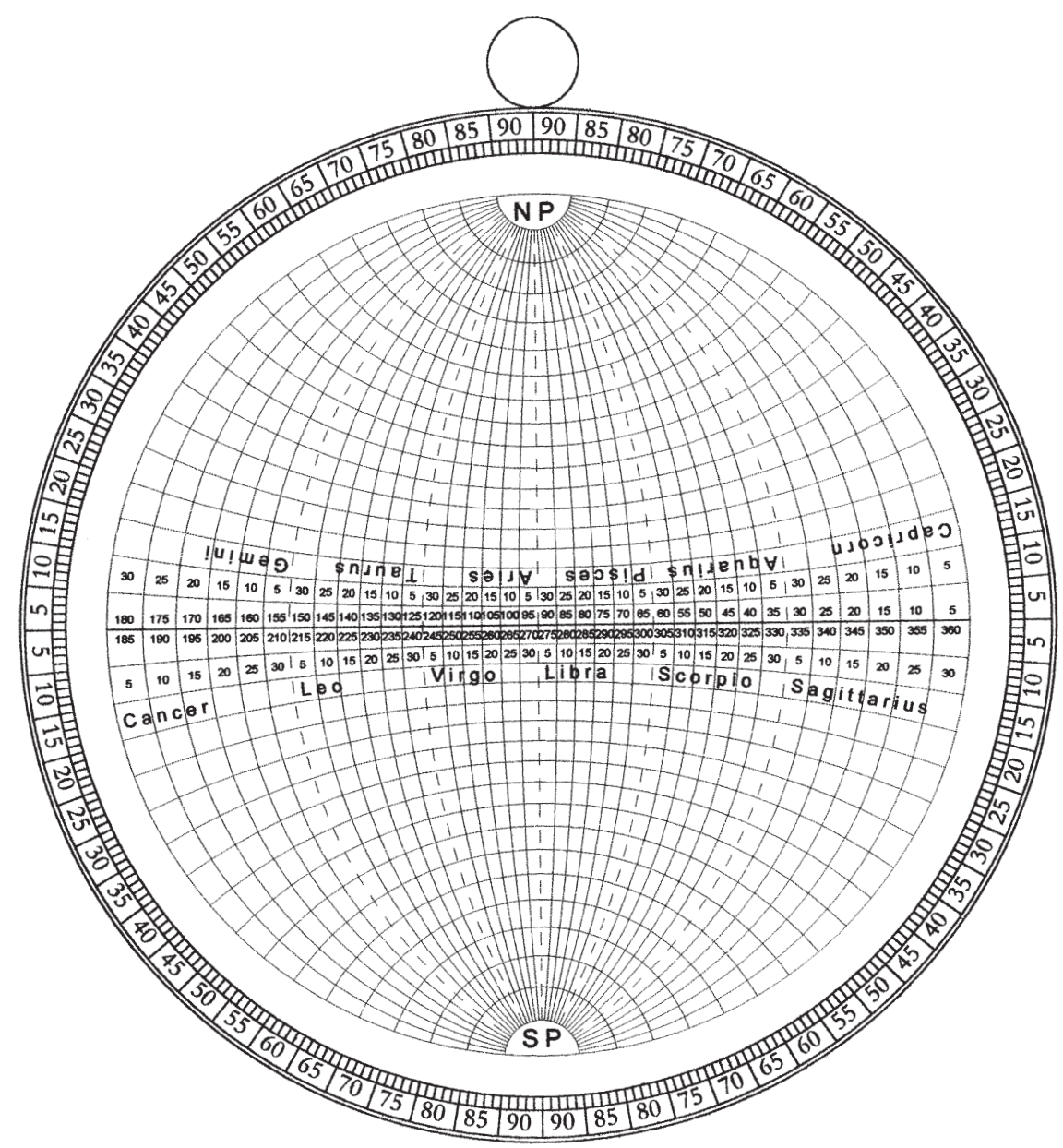

Fig. 5 Reconstruction of the face of the Universal Plate 


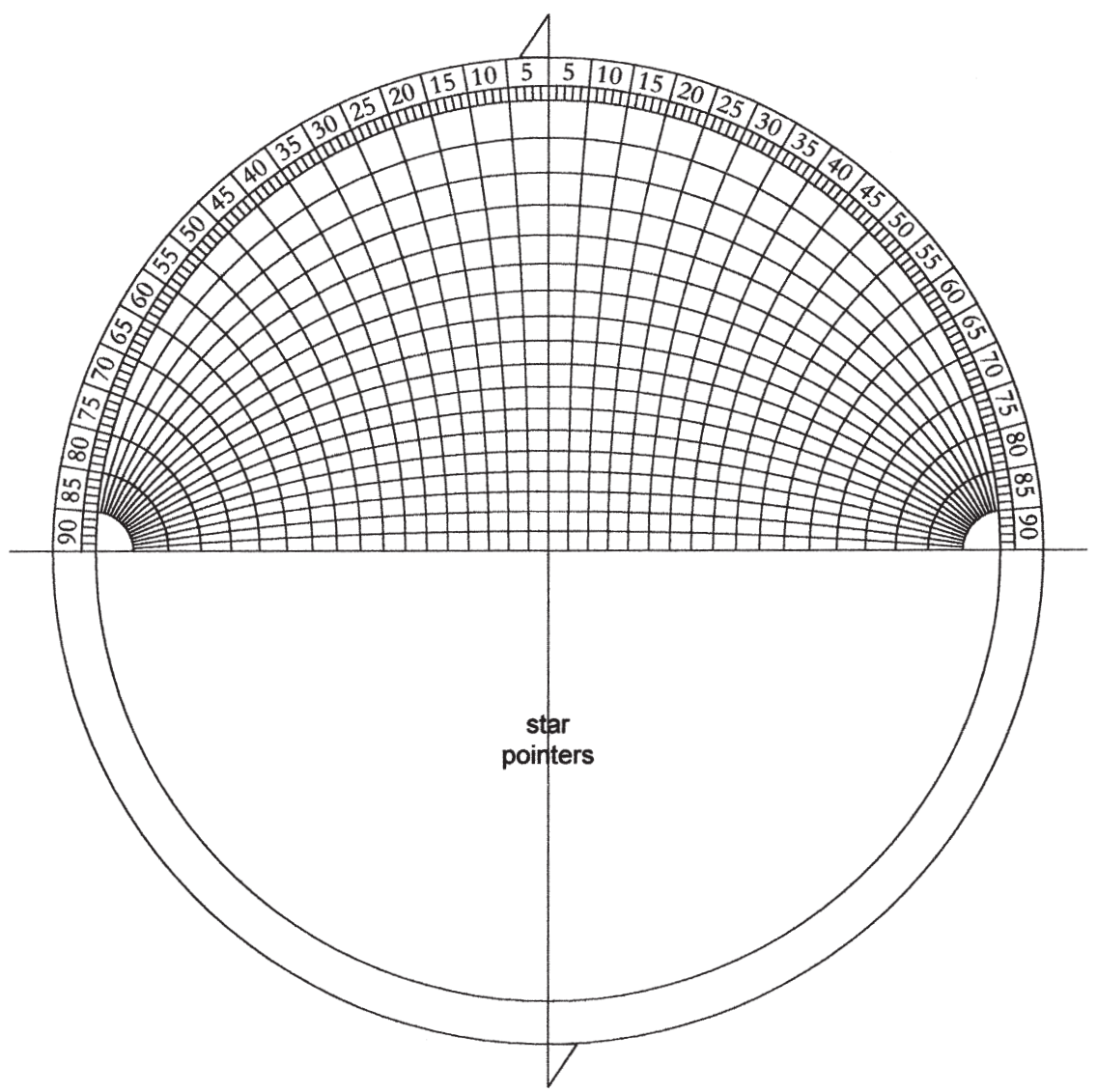

Fig. 6 Reconstruction of the rete of the Universal Plate 


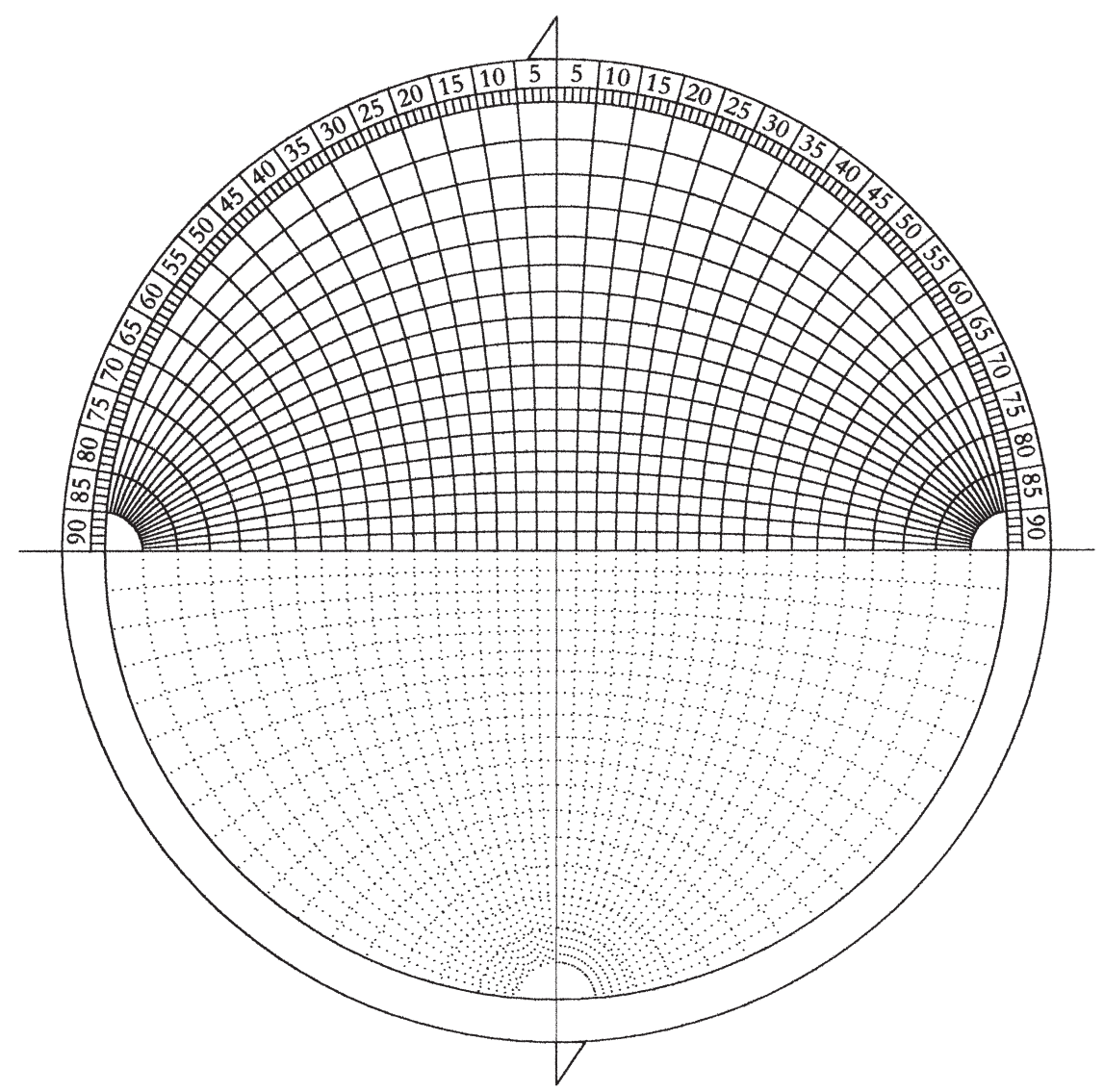

Figure 7 


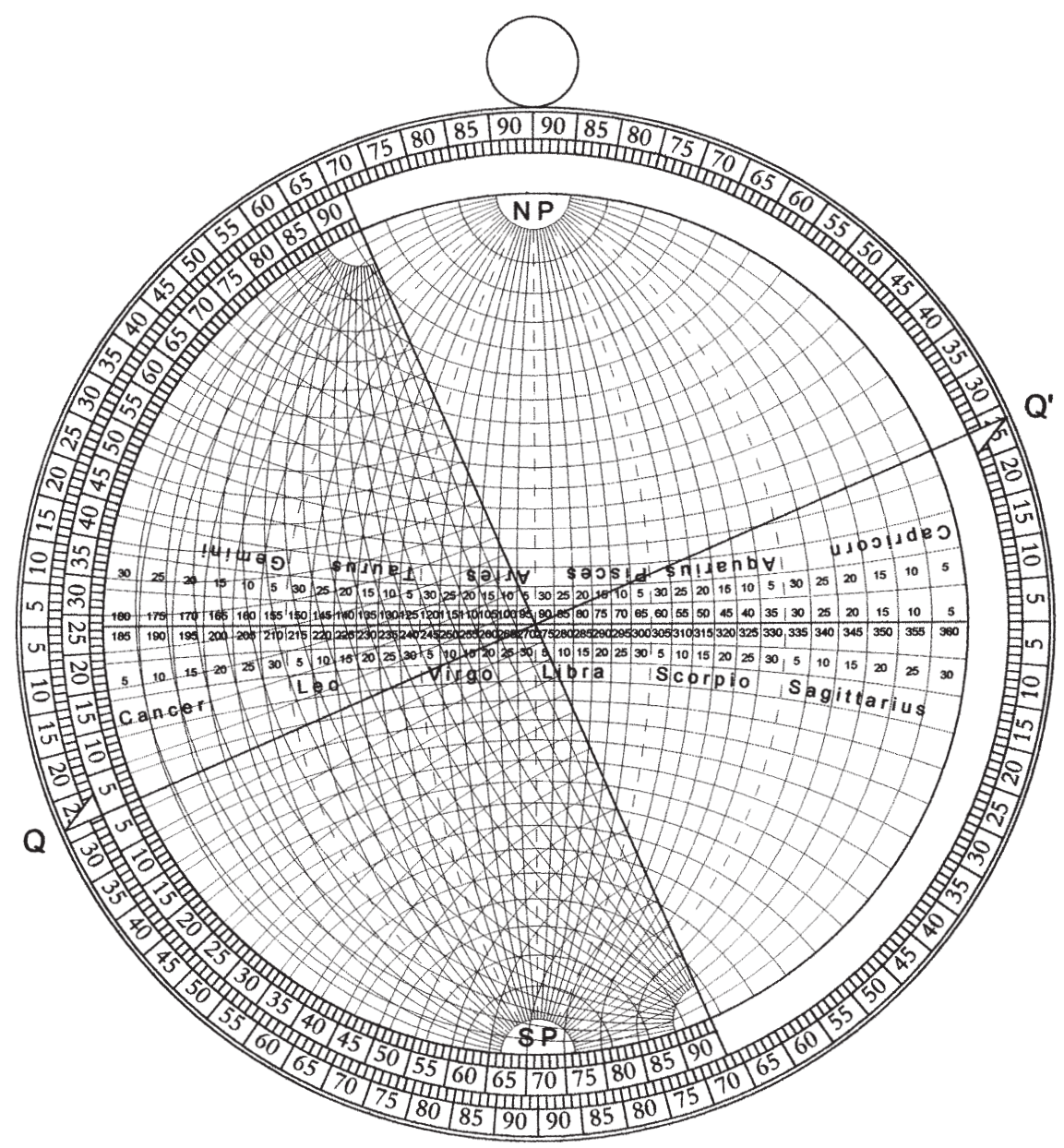

Figure 8 


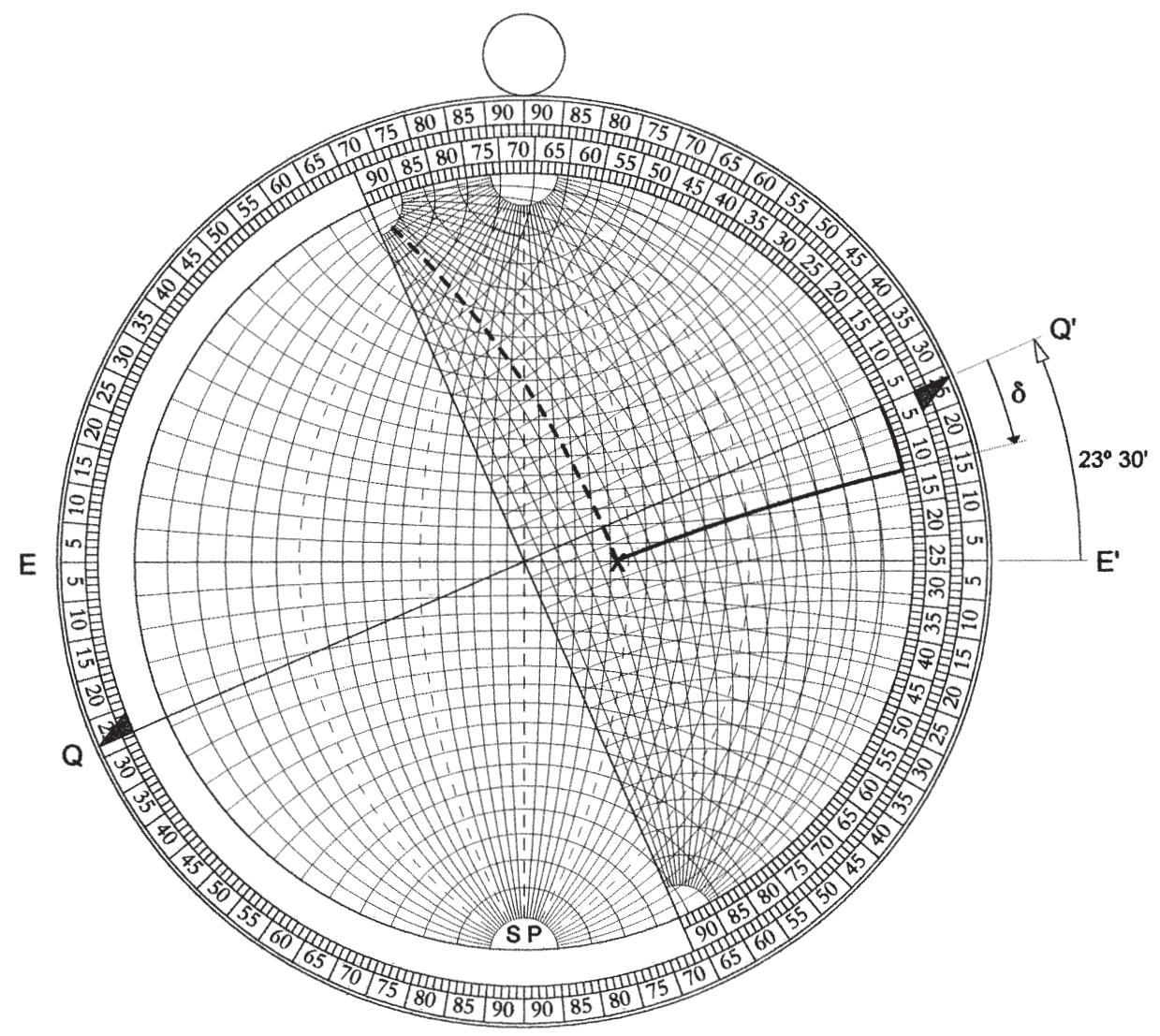

Figure 9 


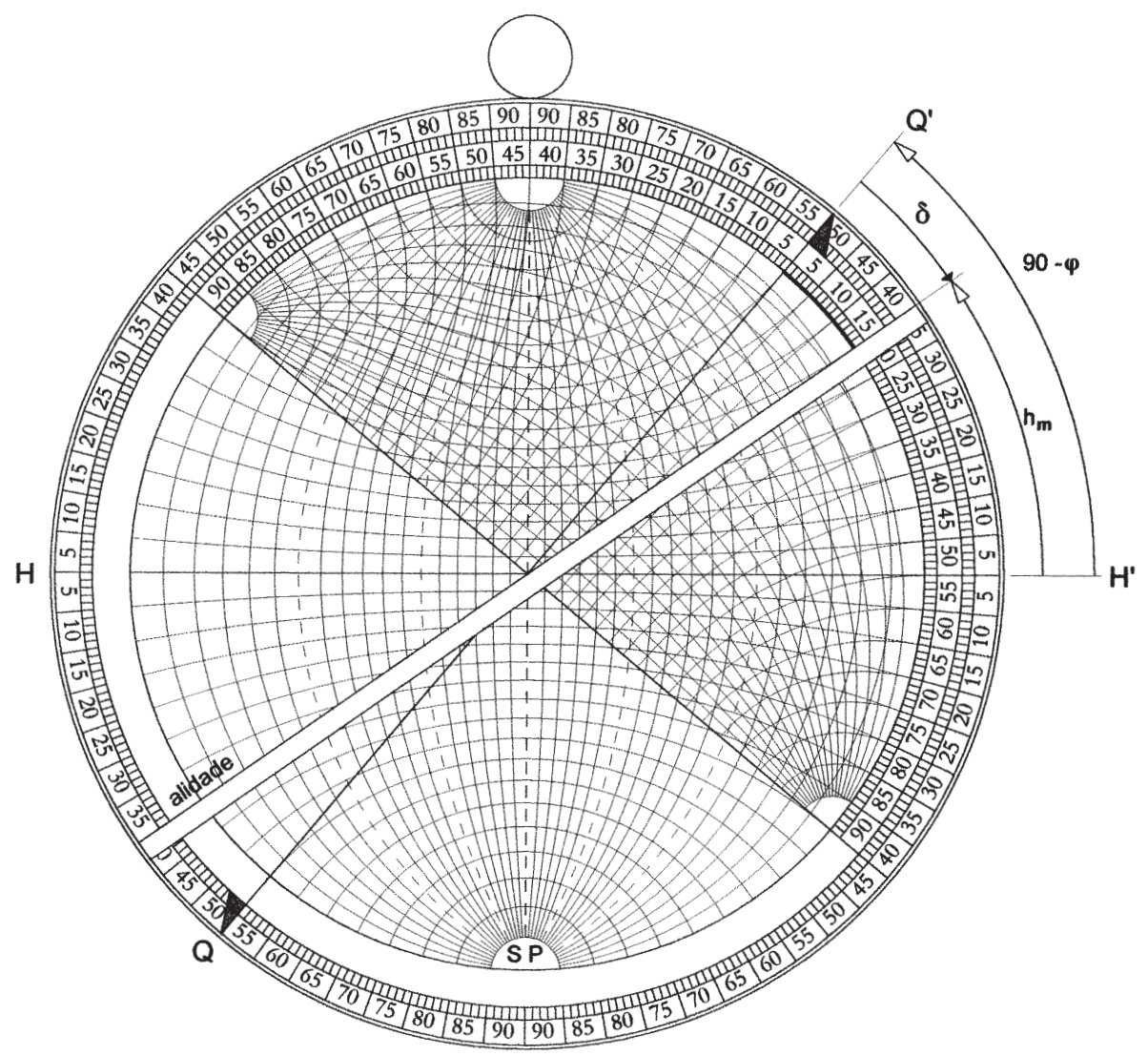

Figure 10 
